\title{
湖沼堆積物の熱ルミネセンスデジタル写真撮影とその色特性
}

\section{Thermoluminescence digital images of lake sediments and their color characteristics}

\section{稲垣亜矢子* 長谷部徳子 $* *$ 遠藤徳孝*** 伊藤一充 ${ }^{*}$ 湯本仁亨 $* * * *$ 柏谷健二**}

Ayako Inagaki ${ }^{*}$, Noriko Hasebe ${ }^{* *}$, Noritaka Endo ${ }^{* * *}$, Kazumi Ito*, Masayuki Yumoto ${ }^{* * * *}$ and Kenji Kashiwaya ${ }^{* *}$

2010 年 4 月 3 日受付. 2010 年 6 月 19 日受理.

* 金沢大学大学院自然科学研究科

Graduate School of Natural Science and Technology, Kanazawa Univ.

***金沢大学環日本海域環境研究センター

Institute of Nature and Environmental Technology, Kanazawa Univ.

**** 金沢大学理工学研究域自然システム学系

College of Science and Engineering, Kanazawa Univ.

****金沢大学理学部地球学科

Department of Earth Science, Faculty of Science, Kanazawa Univ.

Corresponding author; A. Inagaki

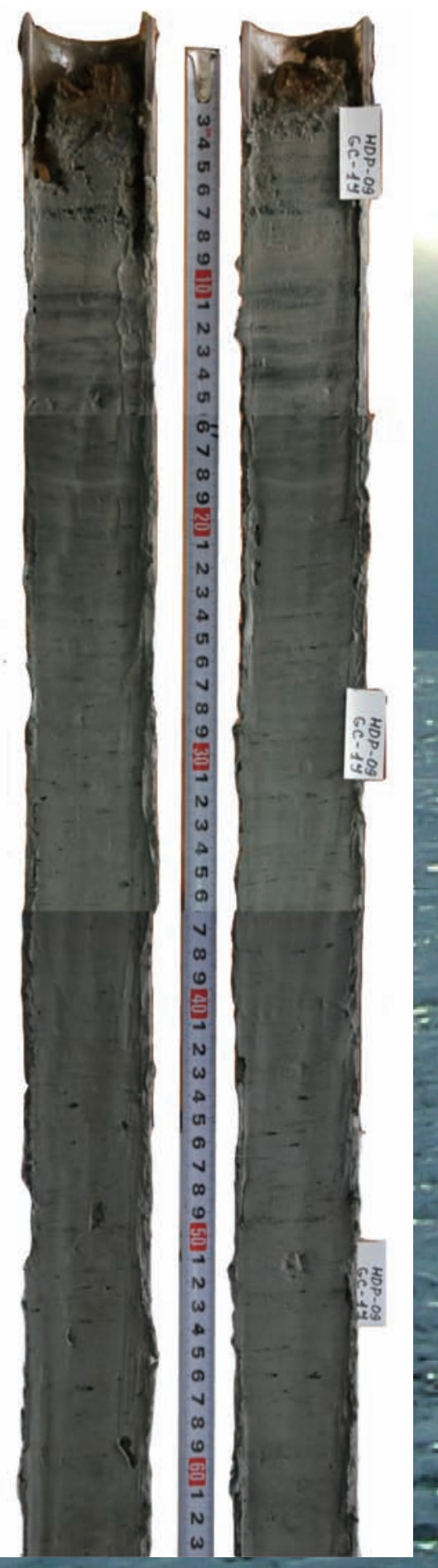

Fig. 2. A sampled core from lake Hovsgol.

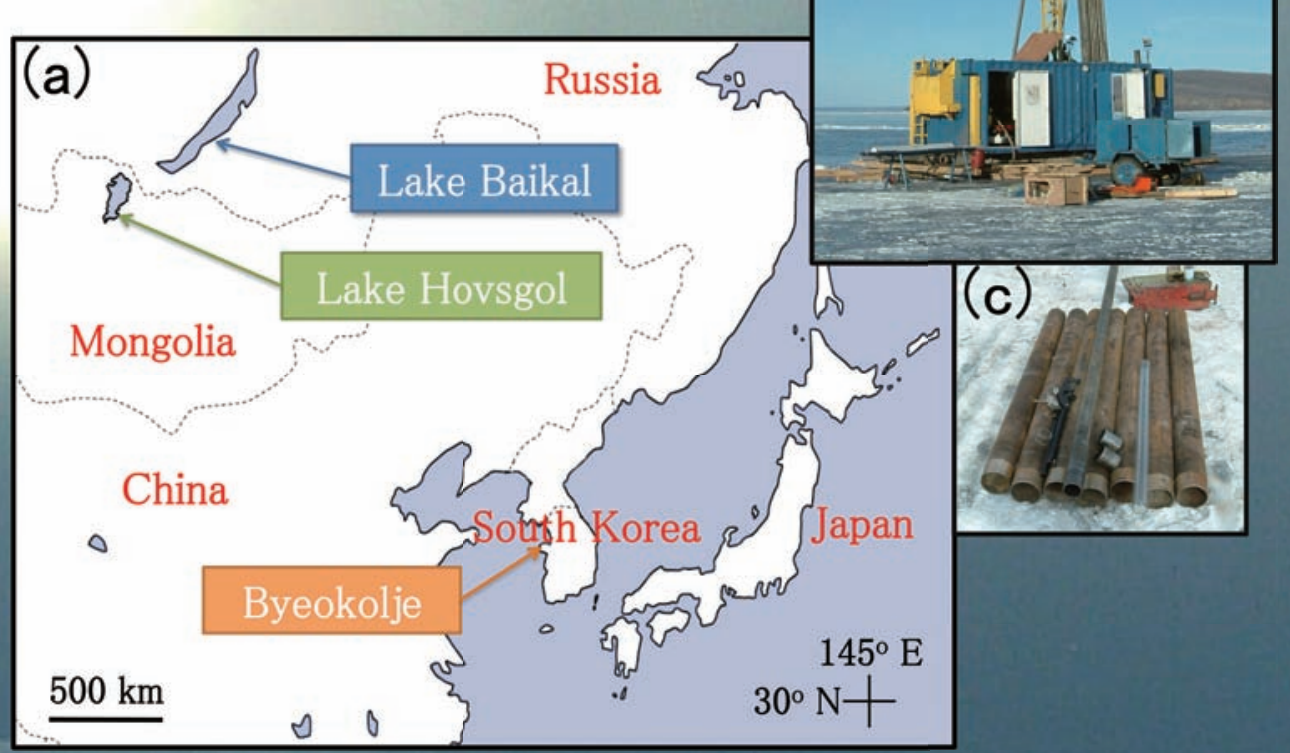

Fig. 1. (a) Locality of lakes where sediments were sampled for thermoluminescence color images. (b) Photo of drilling site in lake Hovsgol, Mongolia. (c) The core tubes for drilling. 


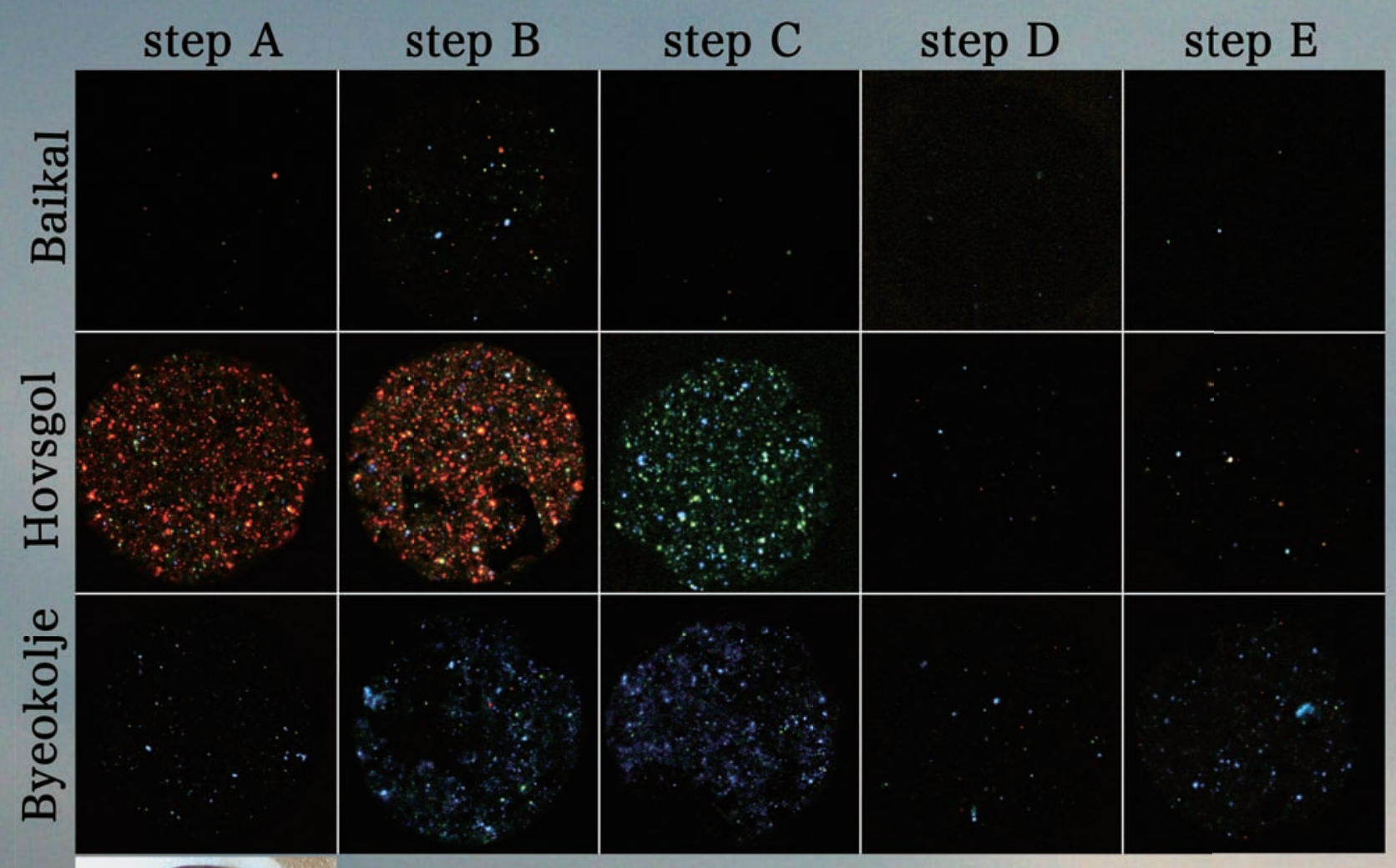

Fig. 3. Thermoluminescence color images (TLCI) after image enhancement. Steps from A to E represent samples after different chemical treatment.

Step A: original sample.

Step B: after $\mathrm{H}_{2} \mathrm{O}_{2}$ treatment. Step C: after $\mathrm{HCl}$ treatment. Step D: after $\mathrm{H}_{2} \mathrm{SiF}_{6}$ treatment. Step E: after HF treatment. TLCI shows distinctive colors from lake to lake. TLCI from lake Hovsgol remarkably changes from step B to step C.
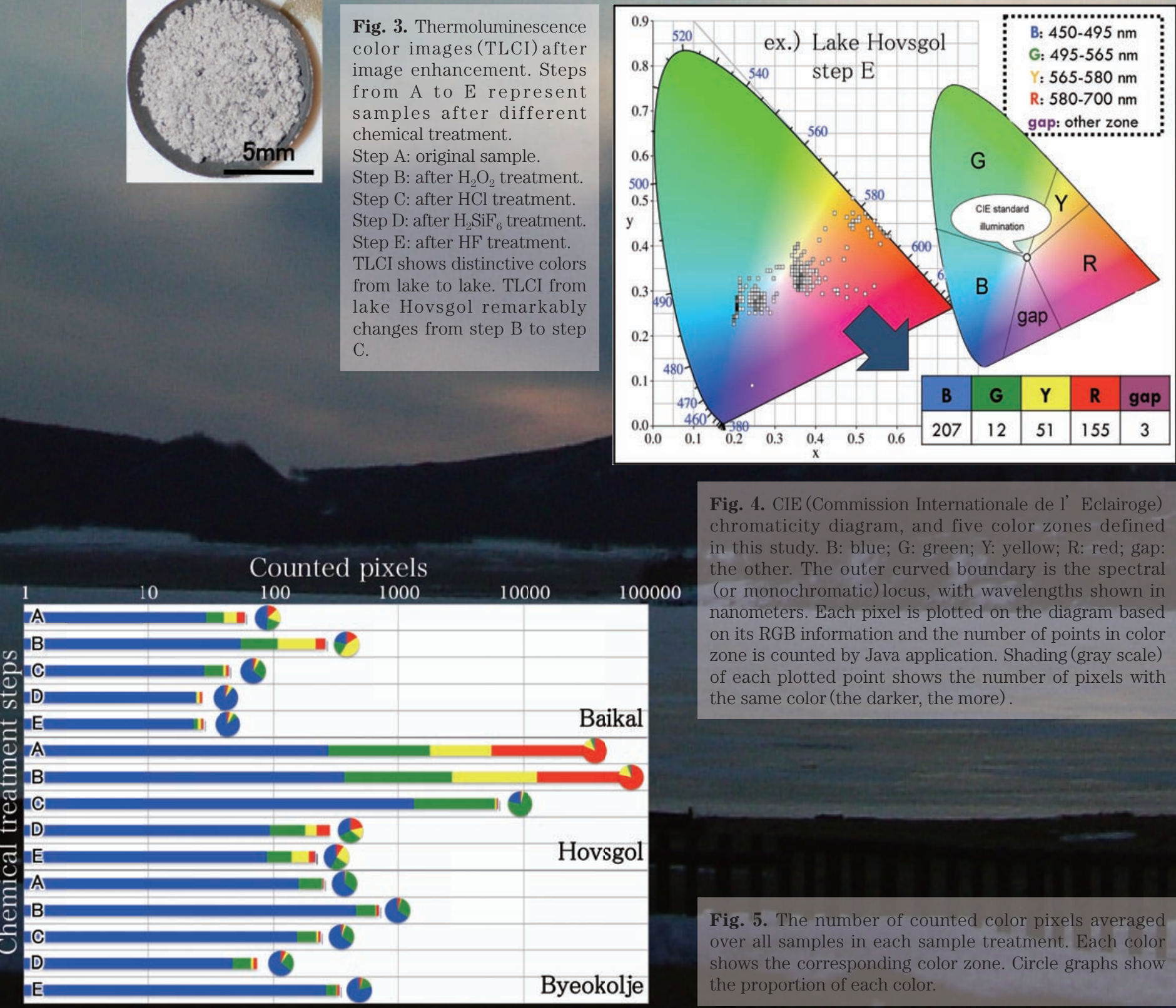

Fig. 4. CIE (Commission Internationale de l' Eclairoge) chromaticity diagram, and five color zones defined in this study. B: blue; G: green; Y: yellow; R: red; gap: the other. The outer curved boundary is the spectral (or monochromatic) locus, with wavelengths shown in nanometers. Each pixel is plotted on the diagram based on its RGB information and the number of points in color zone is counted by Java application. Shading (gray scale) of each plotted point shows the number of pixels with the same color (the darker, the more).

Fig. 5. The number of counted color pixels averaged over all samples in each sample treatment. Each color shows the corresponding color zone. Circle graphs show the proportion of each color. 